\title{
Inflation Targeting and Economic Growth: Case of Albania
}

\section{Güngör Turan}

Phd in Economics, Department of Economics, Epoka University, Tirana gturan@epoka.edu.al

\section{Ornela Rajta}

MSc student in Banking and Finance, Epoka University, Tirana ornela.rajta@gmail.com

\section{Doi:10.5901/ajis.2015.v4n3s1p403}

\section{Abstract}

\begin{abstract}
The purpose of this paper is the impact of the variable "Inflation targeting" in Albanian economic growth over the years. The paper examines the role of inflation targeting on economic growth in Albania for the period 1991-2013, focusing briefly on the performance and the determinants of each of these indicators. The decrease or increase of the Albanian economy has many factors that influence its performance. Econometric tests developed in this paper, shows how this variable was stable and how it has affected the economic growth. Econometric analysis shows that inflation targeting effect economic growth but not the opposite. Inflation targeting and economic growth in Albania have a negative correlation.
\end{abstract}

Keywords: Inflation targeting, economic growth

\section{Introduction}

Various authors have made analyzes of inflation targeting regimes that are applied by different countries. So there are no strict rules for the implementation of this regime. This type of procedure can be implemented by developing countries, developed countries, even in countries that do not have well structured economic structures. Albania decided to implement inflation targeting regime because since monetary policy cannot predict the future inflation. Some main benefits of inflation targeting are; understandable by the public, improved automatically; it has high flexibility to deal with high shocks.

Albania is a transit country that faced many problems in developing a stable economy by trying to keep macroeconomic factors stable. One of them is inflation. Starting from 1990, when Albania passed from one regime to other real economic difficulties arisen (Shqipërisë, 2014). Price liberalization in 1992 was followed by inflation rates threedigit level. Stabilization package, implemented since then, proved was effective. In 1995, the decline in economic activity was recovered; the inflation rate fell to 6 percent, while the balance of payments showed signs of improvement. Flowering and the collapse of pyramid schemes in 1996-1997, was a major step back on the path of macroeconomic stabilization. Frequent economic activity brought drop production, while the inflation rate reached 42 percent (INSTAT).

Despite the consolidated performance of the main indicators, Macroeconomic stability is still unconsolidated and the success of monetary policy cannot be considered mature. Monetary targeting regime becomes even more challenging, if the distinction between inflation performance and the performance of the monetary targeting regime.

This paper aims to answer the questions: Is inflation target effective in the economic growth of Albania? If yes, what is the effect measured in quantitative form? What can be said about the direction of causality between these two indices? The methodology used is based on econometric analysis on the time series regression (OLS), which takes into account a structural fracture data. Both sets used are targeted inflation and real economic growth, which are annual data, measured in percentage, and cover the period 1991-2013.

\section{Literature Review}

Inflation is the most challengeable factor to be kept under control; while economic growth is the main target of every developing economy. According to (Tobin, 1965), inflation has an impact on economic growth, differently known as Tobin theorem. He states that there exists a positive influence of inflation in economic growth. Hence, there exist a contra effect 
or theorem which states that inflation has a negative effect of economic growth (Stockman, 1981). This effect is known as Stockman effect or anti Tobin effect.

Most economists favor a low positive and stable inflation because low inflation can reduce the "severity" of the economic recession and the risk of destabilization of the economy (Stockman, 1981)and (Phelp, 1967) High inflation is unsustainable. This statement is known as the theorem "Friedman". The theorem shows the relationship between economic growth and inflation without including uncertainty, while the second way studies this relationship including both inflation and economic growth uncertainty (Friedman, 1997), (Phillips, 1958). Most countries use inflation targeting to bring inflation in low levels. Economists argue if inflation targeting has a positive or negative impact in economic growth. Recent studies bring mixed effects.

According to (Mishkin, 1990), inflation targeting leads to real economic growth. (Posen, 1997)Made an analyze of inflation target impact on economy on three countries that used IT as regime for the first time like Canada, New Zealand and UK. He reached a conclusion that inflation targeting appeared to have a positive effect on economic growth, lowered inflation in these countries and served to keep inflation under control which was relatively high especially in New Zealand. Also (Walsh, 2009) found that inflation targeting had lead to a decrease of inflation in the countries that used this regime and has a better economic performance than the countries that haven't adopted IT. (Sidrauski, 1967) stated that inflation has no effect on output.

On the other hand, stated that "there does not exist evidence that prove inflation targeting have influence on economic growth or economic overall performance. Even concluded that there is not empirical evidence for either positive or negative relationship. On their study (De Gregorio, 1993) and (Barro, 1995) while analyzing data for 12 American Countries during 1950-1985, found that inflation targeting have a negative effect economic growth.

(Judson, 1999)And in their cross-sectional time-average regression analyze found that there exist a strong negative correlation between inflation targeting and income growth. Even there does not exist a theoretical and empirical agreement about inflation targeting, it is accepted and applied by central banks. According to Albania case, studies made for the impact of inflation targeting and economic growth are mixed too.

(Bolle, 2005)Argue, the inflation premium, expressed in show that inflationary expectations are still not consolidated Boa target close. Argue, the performance of this monetary regime is considerably weaker than the performance of inflation itself.

\section{Data and Methodology}

Being a country in transition, Albania constitutes a challenging case for the application of statistical models. Lack of data, ongoing structural changes, difficulties in assessing future development of exogenous variables, uncertainties in the monetary transmission mechanism and the short experience in modeling, constitute some of the main difficulties.

Total variables that are taken for analysis are: inflation targeting (taken as percentage of change in inflation occurred in certain years from IT) and real economic growth because other variable in the model were invalid. In the following analysis, inflation targeting is recorded as IT and variable economic growth will be marked as REKV.

As we study the impact of inflation on economic growth model is generalized:

\section{REKV $=\beta_{0}+\beta_{1}^{*} I T+u_{t}$}

Where:

IT $\rightarrow$ inflation targeting as independent variable

$\mathrm{REKV} \rightarrow$ economic growth as dependent variable

$\beta_{0}+\beta_{1} \rightarrow$ slope indicating the change of REKV on average when IT increases one unit

Analyze of the model will begin by studying stationary of variables. Stationary of a series affects the behavior and its properties (Baltensperger Ernst, 2007). For the test series stationary it is used Dickey-Fuller test. DF assuming uncorrelated remains was among them. Referring the model:

$$
\Delta Z_{t}=\beta_{1}+\delta Z_{t-1}+\sum_{i=1}^{p} \gamma_{i} \Delta Z_{t-i}+u_{t}
$$

Building the Hypotheses:

$\mathrm{H}_{0}: \delta=0$ ( equivalent to the existence of unitary root)

The alternative hypothesis: $\mathrm{H} 1: \delta<0$ (time series is stationary) 
Table 1: Stationary test for REKV variable

Null Hypothesis: REKV has a unit root

Exogenous: Constant

Lag Length: 0 (Automatic - based on SIC, maxlag=4)

\begin{tabular}{llcl}
\hline \hline & & t-Statistic & Prob. $^{*}$ \\
\hline \hline Augmented Dickey-Fuller test statistic & & 0.886781 & 0.9932 \\
\hline Test critical values: & 1\% level & -3.769597 & \\
& $5 \%$ level & -3.004861 & \\
& $10 \%$ level & -2.642242 &
\end{tabular}

Null Hypothesis: D(REKV) has a unit root

Exogenous: Constant

Lag Length: 0 (Automatic - based on SIC, maxlag=4)

\begin{tabular}{lll}
\hline \hline & & t-Statistic Prob. \\
\hline \hline Augmented Dickey-Fuller test statistic & & -5.6368330 .0002 \\
\hline Test critical values: & 1\% level & -3.788030 \\
& $5 \%$ level & -3.012363 \\
& $10 \%$ level & -2.646119 \\
\hline \hline
\end{tabular}

*MacKinnon (1996) one-sided p-values.

From Table 1, results show that that the t-statistics observed for the variable REKV is:

$\mathrm{t}_{\text {observed }}=0.886$ which is greater than any critical value shown in the table, therefore $\mathrm{HO}$ is accepted, so this variable is non-stationary .

To turn it stationary differentiate REKV variable, analyzing in the same way variable $D$ (REKV). Test results are provided in the second table. From the t-statistics observed it is shown that: tobserbed $=-5636<T_{K R}=>H_{0}$ is accepted. The series $D$ (REKV) is stationary or REKV series is stationary to order 1.

To assess whether or not the model is stationary, it must be considered if the second variable is stationary: inflation targeting (IT). The test on which we rely is again ADF test and test results are given in the two tables below:

Table 2: Stationary test for IT variable

Null Hypothesis: IT has a unit root

Exogenous: Constant

Lag Length: 2 (Automatic - based on SIC, maxlag=4)

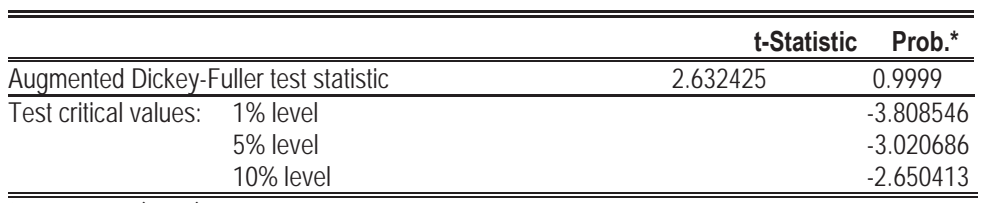

*MacKinnon (1996) one-sided p-values.

Null Hypothesis: D(IT) has a unit root

Exogenous: Constant

Lag Length: 0 (Automatic - based on SIC, maxlag=4)

\begin{tabular}{lccc}
\hline \hline & & t-Statistic & Prob. $^{*}$ \\
\hline \hline Augmented Dickey-Fuller test statistic & & -6.745974 & 0.0000 \\
\hline Test critical values: & $1 \%$ level & -3.788030 & \\
& $5 \%$ level & -3.012363 & \\
& $10 \%$ level & -2.646119 & \\
\hline \hline
\end{tabular}


From Table 2, results that the t-statistics observed for IT is variable:

tobserved $=2.63>\mathrm{TKR} \Rightarrow \mathrm{HO}$ stands, so this variable appears non-stationary. To turn on the stationary variable differentiate IT, analyzing variable D (IT). Test results are provided in the second table. It is noted that the t-statistic is observed:

tobserved $=-6745<T_{K R} \Rightarrow>H 0$ is not true, the series is stationary. Because both series come non-stationary, but with a return time difference stationary so result that both variables are stationary to order 1.

\subsection{Johansen Cointegration test}

Often in economy it is necessary to see if two time series which have a short term relation, are in equilibrium even in long term, meaning if they co-integrate. During the analysis of this test, we must consider the variables:

Hypotheses for this test are:

$\mathrm{H}_{0}: \mathrm{r}=\mathrm{O} \rightarrow$ no co-integrating series

$\mathrm{H}_{\mathrm{a}}: \mathrm{r} \geq 1 \rightarrow$ has at least one cointegrating series

Table 3: Johansen test results

\begin{tabular}{lrrrr}
\multicolumn{3}{l}{ Unrestricted Cointegration Rank Test (Trace) } \\
\hline \hline $\begin{array}{l}\text { Hypothesized } \\
\text { No. of CE(s) }\end{array}$ & $\begin{array}{r}\text { Trace } \\
\text { Eigenvalue }\end{array}$ & $\begin{array}{r}\text { Statistic } \\
\text { Critical Value }\end{array}$ & Prob.** $^{*}$ \\
\hline \hline None * & 0.639950 & 21.68858 & 15.49471 & 0.0051 \\
At most 1 & 0.167571 & 3.301331 & 3.841466 & 0.0692 \\
\hline \hline
\end{tabular}

In case where there doesn't exist any cointegrating variable observed $=21.68>$. In this case critical trace stat $=15.49 \rightarrow$ so $\mathrm{H}_{0}$ fails, so there exist at least one cointegrating series in long run. Again it is build hypotheses, to see if this connection is stable:

$\mathrm{H}_{0}: \mathrm{r}=1 \rightarrow$ there is only one series in the long-term cointegrating

$\mathrm{H}_{\mathrm{a}}: \mathrm{r}>1 \rightarrow$ more than one series sin long-term cointegrating.

As a result from statistics trace values in the second row of the table:

Statistical values observed- trace $=3.30<$ stat Critical trace $\mathrm{H}_{0}=3.84 \rightarrow \mathrm{H}_{0}$ accepted

So inflation targeting variable affects Economic Growth in the short term and in the long term.

\subsection{Granger test}

To test whether an economic indicator cause another test can help us standard Granger causality (Granger, 1988) which tries to determine past value of a variable that help to predict changes in another variable.

Hypothesis 1:

$\mathrm{H}_{0}:$ IT = I> REKV $\rightarrow$ Inflation targeting does not affect economic growth

$\mathrm{H}_{\mathrm{a}}$ IT $\mathrm{IT}$ REKV targeted $\rightarrow$ Inflation targeting affects economic growth

Also an economic growth variable assumption is:

Hypothesis 2:

$\mathrm{H}_{0}$ : REKV $=>>$ IT $\rightarrow$ Economic growth does not affect Inflation Target

$\mathrm{H}_{\mathrm{a}}: \mathrm{REKV}=>\rightarrow \mathrm{IT}$ affects economic growth

Table 4: Granger test results

Pairwise Granger Causality Tests

Date: 05/11/14 Time: 00:09

Sample: 19912013

Lags: 1

\begin{tabular}{lccc}
\hline \hline \multicolumn{1}{c}{ Null Hypothesis: } & Obs & F-Statistic & Prob. \\
\hline \hline IT does not Granger Cause REKV & 22 & 7.16518 & 0.0149 \\
REKV does not Granger Cause IT & & 0.03044 & 0.8633
\end{tabular}


Note: for $p$-value $<\mathrm{a}=$ 00:05 $\Rightarrow$ rejected $\mathrm{HO}$

a) To study the impact when the public debt on economic growth, we see from the table that the observed Fisher statistics Fv $=7.16>=5 \rightarrow \mathrm{F}_{\text {critc }} \mathrm{H}_{0}$ fails

Inflation affects the variable of economic growth.

The impact of economic growth on inflation targeting variable, results from the table show that the observed Fisher statistics Fv $=00: 03<_{\text {Fcritc }}=5 \rightarrow \mathrm{H}_{0}$ accepted.

Economic growth does not affect the inflation targeting variable.

With these results it is answered the question of causation response between these two variables.

So, according to this test, there exists causality with only one direction, moving from inflation targeting to growth.

\subsection{Impulse response}

Graph 1: Impulse response

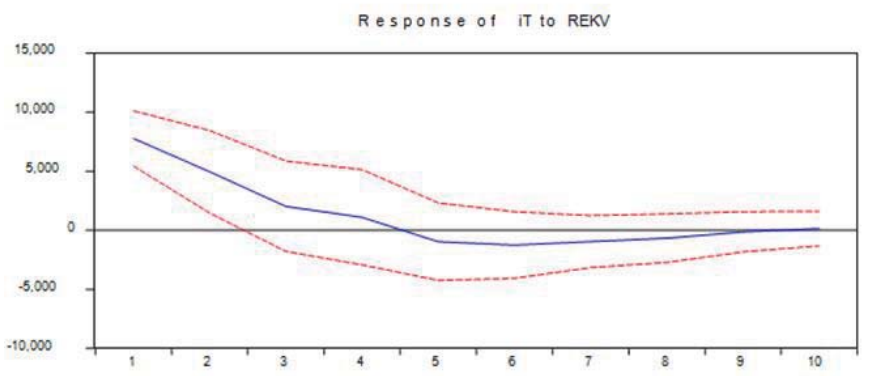

Impulse responses are graphic view that shows the impact of one variable with another with passing time. The graph of impulse responses shows that there is negative relation between inflation targeting and economic growth. This is shown by the inner full line which is slightly IT on economic growth.

\section{Conclusion}

This paper tasted the relationship of inflation targeting and economic growth and the effect of inflation targeting in economic performance of Albania. Two variables are taken in consideration, inflation targeting as independent variable and economic growth as dependent variable. Results from Johansen Cointegration test shows that inflation targeting effect inflation in short and long term. Granger results show that Economic growth does not affect the inflation targeting variable. From impulse responses it can be concluded that inflation targeting and economic growth in Albania have negative correlation.

\section{References}

Baltensperger Ernst, F. A. (2007). Strong goal independence and inflation target. Journal of political economy 23(1): 88-105.

Barro, R. S.-i.-M. (1995). Economic Growth. McGraw-Hill, New York 1: 1-27.

Bolle, M. M. (2005). the Effectiveness of Monetary policy in Albania and the need for further reform. central bank, open debate Vol. 7 , No. 4, pp. 22-28.

De Gregorio, J. (1993). Inflation, taxation and long-run growth. Journal of Monetary Economics 31: 271-298.

Fischer, S. (1993). The role of macroeconomic factors in growth. Journal of Monetary Economics 32 (3), 485-511.

Friedman, M. (1997). Nobel Lecture: Inflation and Unemployment. Journal of Political Economy 85, pp. 451-472.

Granger, C. (1988). Causality, Cointegration, and Control,". Journal of Economic Dynamics 39, 199-211.

INSTAT. inflacioni nder vite. 2014.

Johnson, H. (1967). Is inflation a retarding factor in economic growth? third Rehoroth conference. p121-130.

Judson, R. a. (1999). Inflation, volatility and growth. international finance, 2:1, 117-138.

Luçi, E. I. (2005). . "A Review of Albanian Monetary, targeting effect. Central bank, open debate.

Mishkin, F. (1990). Can Inflation Targeting Work in Emerging Market Countries? NBER Working Paper 43 (3): 579-605. 
Phelp, E. S. (1967). Phillips curve, expectations of inflation and optimal employment over time. Economica, 34(3) p $254-281$.

Phillips, A. W. (1958). The relation between unemployment and the rate of change of money wage rates in the UK. Economica, pp.283299.

Posen, M. a. (1997). Inflation Targeting: Lessons from Four Countries. International security, 21: 5-53.

Sidrauski, M. (1967). Inflation and economic growth. Journal of Political Economy, 57, 534-544.

Stockman, A. C. (1981). Anticipated inflation and the capital stock in a cash in advance economy. Journal of Monetary Economics, 8 : 587- 601.

Svennson. (1999). "Inflation Targeting as a Monetary Policy Rule.”. NBER Working paper No. 6790.

Shqipërisë, B. e. (2014). "Zhvillimi Financiar dhe Rritja Ekonomike: Rasti I Shqiperise. Buletini i bankes se Shqiperise, pp12- 16. Tobin. (1965). Money and economic growth. Econometrica, 33 (4), 671- 684.

Walsh. (2009). “Inflation Targeting: What Have We Learned?". International Finance, Vol 12 (2) pp 195- 233. 